\title{
Effect of respiratory therapy on patients with sleep bruxism and associated respiratory events: Study protocol for a randomized controlled clinical trial
}

Efeito da terapia respiratória em pacientes com bruxismo do sono e eventos respiratórios associados: Protocolo de ensaio clínico randomizado controlado

Efecto de la terapia respiratoria en pacientes con bruxismo del sueño y eventos respiratorios asociados: Protocolo de estudio para un ensayo clínico controlado aleatorizado

Bianca Lopes Cavalcante-Leão ORCID: https://orcid.org/0000-0002-6170-1914 Universidade Tuiuti do Paraná, Brazil E-mail: bianca.leao@utp.br José Stechman-Neto

ORCID: https://orcid.org/0000-0002-0259-2420 Universidade Tuiuti do Paraná, Brazil E-mail: stechman1@gmail.com

Glória Cortz Ravazzi

ORCID: https://orcid.org/0000-0002-6574-9878 Universidade Tuiuti do Paraná, Brazil E-mail: gcortz@cortz87@hotmail.com

Anne Elise Sarraf Fischer ORCID: https://orcid.org/0000-0002-0104-2638 Universidade Tuiuti do Paraná, Brazil E-mail: annesarraff@hotmail.com

Yasmin Abdula

ORCID: https://orcid.org/0000-0002-5858-9052 Universidade Tuiuti do Paraná, Brazil E-mail: yasassad@hotmail.com

Miguel Meira e Cruz

ORCID: https://orcid.org/0000-0001-6076-0878

European Sleep Center, Portugal

Universidade de Lisboa, Portugal

E-mail: mcruz@medicina.ulisboa.pt

Rosane Sampaio Santos

ORCID: https://orcid.org/0000-0001-6400-5706 Universidade Tuiuti do Paraná, Brazil E-mail: rosane.santos2@utp.br

Bianca Simone Zeigelboim

ORCID: https://orcid.org/0000-0003-4871-2683 Universidade Tuiuti do Paraná, Brazil E-mail: bianca.zeigelboim@utp.br

\begin{abstract}
Aim: The aim of this study will be to perform respiratory physiotherapy on patients with sleep bruxism and associated respiratory events (apnea and hypopnea). Methodology: The study will be a randomized, controlled, doubleblind, clinical trial with a sample of individuals with sleep bruxism and associated respiratory events. Respiratory (inspiratory and/or expiratory) physiotherapy will be performed using the THRESHOLD IMT and PEP and the results will be compared to a placebo group. Discussion: Regarding respiratory events, there is a broad variety of possible treatments for sleep apnea depending on the physiopathology, severity and patient preference, with CPAP considered the gold standard. However, data on CPAP are inconsistent, with adherence to therapy reported to be between 45 and $89 \%$. Thus, other forms of treatment are proposed, including respiratory training. Understanding obstructive sleep apnea syndrome as the loss of the dilation strength of the pharynx and the inability to maintain the path open for air, respiratory muscle training could assist in increasing dilation strength, enabling the passage of air during sleep. Taking into consideration that sleep bruxism may be associated with events of apnea and hypopnea, the intervention to treat obstructive respiratory events related to sleep may have a positive impact on events related to sleep bruxism (rhythmic activity of the masticatory muscles). To determine this, we will measure the apnea/hypopnea index (AHI) and number of contractions of the masseter muscle (characteristic of the
\end{abstract}


activity of bruxism) before and after the intervention using polysomnography. Trial registration: The trial was registered with the REBEC platform: RBR-9F6JKM (ensaiosclinicos.gov.br).

Keywords: Sleep bruxism; Respiratory therapy; Sleep apnea.

\section{Resumo}

Objetivo: O objetivo deste estudo será realizar fisioterapia respiratória em pacientes com bruxismo do sono e eventos respiratórios associados (apneia e hipopneia). Metodologia: O estudo será um ensaio clínico randomizado, controlado, duplo-cego, com amostra de indivíduos com bruxismo do sono e eventos respiratórios associados. A fisioterapia respiratória (inspiratória e / ou expiratória) será realizada utilizando o THRESHOLD IMT e PEP e os resultados serão comparados a um grupo placebo. Discussão: Em relação aos eventos respiratórios, existe uma ampla variedade de tratamentos possíveis para a apneia do sono, dependendo da fisiopatologia, gravidade e preferência do paciente, sendo o CPAP considerado o padrão-ouro. No entanto, os dados sobre o CPAP são inconsistentes, com a adesão à terapia relatada entre 45 e $89 \%$. Assim, outras formas de tratamento são propostas, incluindo o treinamento respiratório. Compreendendo a síndrome da apneia obstrutiva do sono como a perda da força de dilatação da faringe e a incapacidade de manter o caminho aberto para o ar, o treinamento muscular respiratório poderia auxiliar no aumento da força de dilatação, possibilitando a passagem do ar durante o sono. Considerando que o bruxismo do sono pode estar associado a eventos de apneia e hipopneia, a intervenção para tratamento de eventos respiratórios obstrutivos relacionados ao sono pode ter um impacto positivo nos eventos relacionados ao bruxismo do sono (atividade rítmica dos músculos mastigatórios). Para determinar isso, iremos medir o índice de apneia / hipopneia (IAH) e o número de contrações do músculo masseter (característica da atividade do bruxismo) antes e após a intervenção por meio de polissonografia. Registro do ensaio: $O$ ensaio foi registrado na plataforma REBEC: RBR-9F6JKM (ensaiosclinicos.gov.br).

Palavras-chave: Bruxismo do sono; Terapia respiratória; Apneia do sono.

\section{Resumen}

Objetivo: El objetivo de este estudio será realizar fisioterapia respiratoria en pacientes con bruxismo del sueño y eventos respiratorios asociados (apnea e hipopnea). Metodología: El estudio será un ensayo clínico aleatorizado, controlado, doble ciego, con una muestra de individuos con bruxismo del sueño y eventos respiratorios asociados. Se realizará fisioterapia respiratoria (inspiratoria y / o espiratoria) utilizando el THRESHOLD IMT y PEP y los resultados se compararán con un grupo de placebo. Discusión: En cuanto a los eventos respiratorios, existe una amplia variedad de posibles tratamientos para la apnea del sueño en función de la fisiopatología, la gravedad y la preferencia del paciente, siendo la CPAP considerada el estándar de oro. Sin embargo, los datos sobre CPAP son inconsistentes, y se informa que la adherencia al tratamiento está entre el 45 y el $89 \%$. Por tanto, se proponen otras formas de tratamiento, incluido el entrenamiento respiratorio. Entendiendo el síndrome de apnea obstructiva del sueño como la pérdida de la fuerza de dilatación de la faringe y la incapacidad de mantener el camino abierto para el aire, el entrenamiento de los músculos respiratorios podría ayudar a aumentar la fuerza de dilatación, permitiendo el paso del aire durante el sueño. Teniendo en cuenta que el bruxismo del sueño puede estar asociado a eventos de apnea e hipopnea, la intervención para tratar los eventos respiratorios obstructivos relacionados con el sueño puede tener un impacto positivo en los eventos relacionados con el bruxismo del sueño (actividad rítmica de los músculos masticatorios). Para determinarlo, mediremos el índice de apnea / hipopnea (IAH) y el número de contracciones del músculo masetero (característico de la actividad del bruxismo) antes y después de la intervención mediante polisomnografía. Registro del ensayo: El ensayo se registró en la plataforma REBEC: RBR-9F6JKM (ensaiosclinicos.gov.br).

Palabras clave: Bruxismo del sueño; Terapia respiratoria; Apnea del sueño.

\section{Introduction}

Bruxism is a recurrent issue in the dental clinic and is charged with uncertainties regarding its diagnosis, the need for treatment and the effectiveness of therapeutic modalities. In some situations, bruxism may be associated with oral problems, such as sensitivity/pain upon palpation of the masticatory muscles, headache and symptoms of temporomandibular disorder (Castroflorio et al, 2015). On other occasions, it may be considered a physiological effect of respiratory and swallowing mechanisms during sleep, in which bruxism is the result of the motor activity required for the increase in the patency of the upper airways through jaw movements (Mayer et al, 20017).

For an understanding of the etiological factors of bruxism, it is necessary to understand its definitions. Sleep bruxism (SB) is defined as a movement disorder during sleep characterized by involuntary motor activity of the masticatory muscles in an episodic and repetitive manner. Muscle contractions, also called rhythmic activity of the masticatory muscles (RAMM) 
during sleep often produce teeth grinding sounds, which are related to sleep bruxism (Kapur et al, 2016). Episodes of RAMM are found in $60 \%$ of the general adult population as physiological activity of the masticatory muscles during sleep (Lavigne et al, 2001). In individuals with sleep bruxism, each maximum contraction during RAMM is threefold more frequent and $40 \%$ shorter in comparison to individuals without sleep bruxism (Hasegawa et al, 2013; Jadidi et al, 2011). This activity is also found in numerous sleep disorders, such as somnambulism, night terrors and obstructive sleep apnea/hypopnea syndrome (Lavigne et al, 2003). Many other forms of masticatory and facial muscle activity also occur during sleep, such as swallowing, coughing, smiling, lip smacking and jaw movements (Lavigne, Manzini e Huynh, 2011).

The consensus in the literature is that the diagnosis of SB has three categories: 'possible', which is based on a selfreport with the use of questionnaires or the patient history part of the clinical examination; 'probable', which is based on the self-report and a clinical examination; and 'definitive', which is based on the self-report, clinical examination and polysomnography, preferably with both audio and video recordings (Lobbezoo et al 2018).

Sleep bruxism may occur alone (primary SB) or with one or several associated comorbidities (secondary SB). In some complex cases, SB should be differentiated from other types of facio-mandibular activity that occur during sleep, such as facio-mandibular myoclonus, respiratory disorders (respiratory effort-related arousals, apnea and hypopnea), abnormal swallowing, gastroesophageal problems (acid reflux), night terrors, dyskinetic movements of the jaw during sleep (dystonia, tremors, chorea and dyskinesia) and sleep-related epilepsy (rare) (Lavigne, Manzini e Huynh, 2011; Carra, Huynh \& Lavigne, 2012). Thus, obstructive sleep apnea/hypopnea syndrome (OSAHS) may be a sleep disorder that is concomitant with SB (Inoko et al, 2004; Kato et al, 2003; Sjoholm et al, 2000; Okeson et al, 1991).

Positive effects have been reported in studies involving inspiratory exercises for individuals with obstructive sleep apnea (Vranish et al 2016; Souza et al 2018; Lin et al, 2020) indicating a direction for effective treatments with greater adherence on the part of patients in comparison to the use of CPAP (Weaver \& Grunstein, 2008; Olsen, Smith \& Oei, 2008). Likewise, expiratory exercises have been successful at improving sleep quality and markers related to obstructive sleep apnea (Kuo, Song, Bernard \& Liao, 2017; Herkenrath et al, 2018).

\section{Methodology}

\section{Objective:}

As sleep bruxism may be related to events of apnea and hypopnea, interventions for the treatment of obstructive respiratory events during sleep could have a positive impact on events related to sleep bruxism (rhythmic activity of the masticatory muscles). Therefore, individuals with sleep bruxism and associated respiratory events (apnea and hypopnea) will be randomized in a double-blind clinical trial to receive therapy with inspiratory exercises (inspiratory group), expiratory exercises (expiratory group) or no intervention (placebo group). The apnea/hypopnea index (AHI) and number of contractions of the masseter muscle (characteristic of bruxism) will be determined before and after the intervention.

The following hypotheses will be tested:

1. The inspiratory exercise promotes a reduction in the AHI.

2. The expiratory exercise promotes a reduction in the AHI.

3. The inspiratory exercise promotes a reduction in the number of contractions of the masseter muscle during sleep.

4. The expiratory exercise promotes a reduction in the number of contractions of the masseter muscle during sleep. 


\section{Design}

The study will be a randomized, controlled, double-blind, clinical trial with a sample of individuals with sleep bruxism and associated respiratory events. Respiratory (inspiratory and/or expiratory) physiotherapy will be performed using the THRESHOLD IMT and PEP and the results will be compared to a placebo (non-intervention) group.

\section{Participants and eligibility}

The population for this phase of the study will be composed of 15 individuals identified with sleep bruxism and associated respiratory events (apnea and hypopnea). Recruitment for the study will begin in December 2019 exclusively in the city of Curitiba, Brazil, until the number of participants is reached.

Inclusion criteria:

1. Age 18 to 65 years;

2. Sleep bruxism and associated respiratory events (mild to moderate apnea and hypopnea) identified through polysomnography.

Exclusion criteria:

1. Age less than 18 years;

2. Use of intraoral splint:

3. Severe apnea/hypopnea;

4. Severe skeletal abnormalities that affect the upper airways;

5. Chronic medical conditions that affect OSAHS, such as stroke.

6. Inability to sign the statement of informed consent.

\section{Recruitment}

Participants will be recruited through a public call via social networks and from among the individuals who seek the University with a complaint of sleep bruxism. Those who meet the eligibility criteria after polysomnography will be included in the study.

\section{Interventions: Allocation}

\section{Randomization and blinding}

A person not otherwise involved in the study will manage this phase of the study, ensuring that the evaluators of the outcome are blinded to the allocation of the participants to the different groups. The website program randomization.com will be used for the generation of the random sequence. The proportion of the three groups (inspiratory, expiratory and placebo) will be 1:1:1.

The evaluator of the main outcome (physician in charge of the polysomnography analysis and therefore evaluator of the pre-intervention and post-intervention AHI, oxygen desaturation index and contractions of the masseter muscle) will be blinded to the allocation. The participants will also be blinded; they will not know to which group they are allocated because they are not familiar with the intervention. Likewise, the person in charge of the data analysis will not be directly involved in the study. 


\section{Interventions}

The participants will be randomly allocated to the Inspiratory Group, Expiratory Group and Placebo Group. The three groups will have the same clinical conditions. The participants will not know to which group they have been allocated.

Maximum respiratory pressures will be determined with the aid of a pressure gauge. The measurement of maximum inspiratory and expiratory pressures (MIP and MEP) is a noninvasive method that is widely used to evaluate the strength of the inspiratory and expiratory muscles (Almeida, Bertucci \& Lima, 2008). MIP and MEP values do not depend only on the strength of the respiratory muscles but also on the lung volume with which the measurements are made and the corresponding elastic recoil pressure of the respiratory system (Silva, 2011).

Pressure readings will be performed prior to initiating respiratory muscle training to determine baseline values and enable the quantification of the increase in muscle strength achieved by the respiratory exercises (Souza et al, 2019). Inspiratory and expiratory muscle strengthening will be based on resistance breathing using nonlinear or linear load devices. The method of choice will be the Threshold $®$ IMT for inspiratory muscle training and Threshold $®$ PEP for expiratory muscle training (Ohayon, Li \& Guilleminault, 2001).

The physiotherapist will first verify the resistance to be applied. The load will be adjusted to $70 \%$ maximum inspiratory or expiratory capacity in the intervention groups. No load will be applied in the placebo group. The load will be adjusted weekly based on a new measurement of maximum respiratory capacity. The intervention will be performed for 12 weeks at a frequency of five times per week and the exercises will consist of 30 respiratory cycles (inspiration + expiration) per day.

\section{Data collection and management}

\section{Plans for data collection and evaluation of results}

The data will be entered onto an Excel spreadsheet by a secondary participant in the study. The baseline data will be entered first and the final data will be entered after the 12-week interventions.

\section{Confidentiality}

The researchers commit to maintaining the confidentiality of the data until the publication of the results in a scientific journal. None of the participants will have their identities revealed.

\section{Statistical methods}

The data collected during the study will be organized and submitted to univariate (descriptive: frequency of variables) and bivariate (association and/or correlation tests and comparisons between groups) statistical analyses. The Student's t-test will be used to determine the effectiveness of respiratory therapy. The significance level will be set at $5 \%$.

\section{Reported adverse events and arms of intervention}

The risk of the study regards expiratory and inspiratory muscle fatigue due to the exercises proposed as therapy. To minimize this possibility, the participants will be accompanied by a physiotherapist with experience in respiratory physical therapy who will immediately suspend the therapy upon observing signs of fatigue and will take the necessary measures to reverse the situation.

\section{Criterion for discontinuing or altering the allocation in the intervention group}

Participants who exhibit signs of respiratory fatigue will be removed from the intervention group and will be excluded 
from the study.

\section{Strategies for ensuring adherence to the interventions}

The patients will be monitored weekly in person and telephone contact will be maintained to encourage the daily performance of the exercises.

\section{Concomitant treatment permitted or prohibited during the clinical trial}

During the interventions, the participant cannot undergo any other treatment for obstructive sleep apnea/hypopnea or sleep bruxism. Moreover, the use of sleeping pills will be prohibited.

\section{Prediction of post-trial care}

At the end of the study, if one therapy proves superior to the other, it will be made available to all participants so that they may perform the intervention with the greater benefit.

\section{Outcomes}

The primary outcomes will be the apnea/hypopnea index (AHI), oxygen desaturation index (ODI) and number of contractions of the masseter muscle per hour, measured by polysomnography. The secondary outcome will be sleep quality measured using Pittsburg Sleep Quality Index. The evaluator of the primary outcomes will be blinded to the allocation of the individuals to the different groups.

\section{Results and Discussion}

An epidemiological study published in 2001 suggests that patients with sleep-related respiratory disorders have a greater chance of exhibiting SB (Hosoya et al, 2014). Despite a weak but significant association between SB and OSAHS, the cross-sectional design of the study did not enable the determination of causality between the two conditions. Through polysomnographic analyses, studies have demonstrated that masticatory muscle activity tends to occur soon after the end of apnea or hypopnea events (Inoko, Shimizu \& Kohno, 2004; Sjoholm et al, 2000; Okeson et al, 1991; Saito et al, 2016). Some studies support the hypothesis described above and conclude that most bruxism events are secondary to apnea and hypopnea events, making apnea a risk factor for SB (Saito et al, 2016). However, these findings are inconclusive, since not all SB events occur in this sequence or have a temporal association with respiratory events (Sullivan, Berthon-Jones \& Eves, 1981). If the theory that bruxism is secondary to apnea and hypopnea is confirmed, an improvement in the respiratory condition could lead to a reduction in the occurrence of bruxism.

Regarding respiratory events, there is a broad variety of possible treatments for sleep apnea depending on the physiopathology, severity and patient preference, with CPAP considered the gold standard (Remmers et al, 1978). However, data on CPAP are inconsistent, with adherence to therapy reported to be between 45 and 89\% (Weaver \& Grunstein, 2008; Olsen, Smith \& Oei, 2008). Thus, other forms of treatment are proposed, including respiratory training. Understanding obstructive sleep apnea syndrome as the loss of the dilation strength of the pharynx and the inability to maintain the path open for air (Van de Heyning et al, 2012), respiratory muscle training could assist in increasing dilation strength, enabling the passage of air during sleep (Stollo et al, 2014; Boutron et al, 2017).

\section{Trial Status}

Recruiting 


\section{Final Considerations}

Among the interventions evaluated in clinical trial have a potencial positive impact on OSA and bruxism symptoms. The therapy with inspiratory and expiratory exercises, can be considered on future an alternative for the management of OSA/bruxism patients, improving the quality of sleep an increase in functional capacity.

This study show a possible treatment option in generating a positive impact on events related to sleep bruxism.

\section{References}

Almeida, I. P., Bertucci, N. R., \& de Lima, V. P. (2008). Variações da pressão inspiratória máxima e pressão expiratória máxima a partir da capacidade residual funcional ou da capacidade pulmonar total e volume residual em indivíduos normais (Variations in maximum inspiratory pressure and maximum expiratory pressure from functional residual capacity or total lung capacity and residual volume in normal individuals). $O$ Mundo da Saúde, 32(2), 176-182. http://dx.doi.org/10.1590/S1413-35552007000500006

Boutron, I., Altman, D. G., Moher, D., Schulz, K. F., \& Ravaud, P. (2017). CONSORT statement for randomized trials of nonpharmacologic treatments: a 2017 update and a CONSORT extension for nonpharmacologic trial abstracts. Annals of internal medicine, 167(1), 40-47. https://doi.org/10.7326/M17-0046

Carra, M. C., Huynh, N., \& Lavigne, G. (2012). Sleep bruxism: a comprehensive overview for the dental clinician interested in sleep medicine. Dental Clinics, 56(2),387-413. https://doi.org/10.1016/j.cden.2012.01.003

Castroflorio, T., Bargellini, A., Rossini, G., Cugliari, G., Rainoldi, A., \& Deregibus, A. (2015). Risk factors related to sleep bruxism in children: A systematic literature review. Archives of oral biology, 60(11), 1618-1624.https://doi.org/10.1016/j.archoralbio.2015.08.014

de Souza Kock, K., Calônico, J. C., Luiz, Â. R., Arent, Y. A., \& Fernandes, I. (2019). Análise da pressão inspiratória com alto e baixo fluxos em resistor alinear (Analysis of inspiratory pressure with high and low flows in line resistor). ASSOBRAFIR Ciência, 6(1), 13-20.

Hasegawa, Y., Lavigne, G., Rompré, P., Kato, T., Urade, M., \& Huynh, N. (2013). Is there a first night effect on sleep bruxism? A sleep laboratory study. Journal of Clinical Sleep Medicine, 9(11), 1139-1145.https://doi.org/10.5664/jcsm.3152

Herkenrath, S. D., Treml, M., Priegnitz, C., Galetke, W., \& Randerath, W. J. (2018). Effects of respiratory muscle training (RMT) in patients with mild to moderate obstructive sleep apnea (OSA). Sleep and Breathing, 22(2), 323-328. https://doi.org/10.1007/s11325-017-1582-6

Hosoya, H., Kitaura, H., Hashimoto, T., Ito, M., Kinbara, M., Deguchi, T., \& Takano-Yamamoto, T. (2014). Relationship between sleep bruxism and sleep respiratory events in patients with obstructive sleep apnea syndrome. Sleep and Breathing, 18(4), 837-844.https://doi.org/10.1007/s11325-014-0953-5

Inoko, Y., Shimizu, K., Morita, O., \& Kohno, M. (2004). Relationship between masseter muscle activity and sleep-disordered breathing. Sleep and Biological Rhythms, 2(1), 67-68. https://doi.org/10.1111/j.1479-8425.2003.00068.x

Jadidi, F., Nørregaard, O., Baad-Hansen, L., Arendt-Nielsen, L., \& Svensson, P. (2011). Assessment of sleep parameters during contingent electrical stimulation in subjects with jaw muscle activity during sleep: a polysomnographic study. European journal of oral sciences, 119(3), 211-218. https://doi.org/10.1111/j.1600-0722.2011.00822.x

Kapur, V. K., Auckley, D. H., Chowdhuri, S., Kuhlmann, D. C., Mehra, R., Ramar, K., \& Harrod, C. G. (2017). Clinical practice guideline for diagnostic testing for adult obstructive sleep apnea: an American Academy of Sleep Medicine clinical practice guideline. Journal of Clinical Sleep Medicine, 13(3), 479. 504.https://doi.org/10.5664/jcsm.6506

Kato, T., Montplaisir, J. Y., Guitard, F., Sessle, B. J., Lund, J. P., \& Lavigne, G. J. (2003). Evidence that experimentally induced sleep bruxism is a consequence of transient arousal. Journal of dental research, 82(4), 284-288. https://doi.org/10.1177\%2F154405910308200408

Kuo, Y. C., Song, T. T., Bernard, J. R., \& Liao, Y. H. (2017). Short-term expiratory muscle strength training attenuates sleep apnea and improves sleep quality in patients with obstructive sleep apnea. Respiratory physiology \& neurobiology, 243, 86-91.https://doi.org/10.1016/j.resp.2017.05.007

Lavigne, G. J., Kato, T., Kolta, A., \& Sessle, B. J. (2003). Neurobiological mechanisms involved in sleep bruxism. Critical Reviews in Oral Biology \& Medicine, 14(1), 30-46. https://doi.org/10.1177\%2F154411130301400104

Lavigne, G. J., Rompre, P. H., Poirier, G., Huard, H., Kato, T., \& Montplaisir, J. Y. (2001). Rhythmic masticatory muscle activity during sleep in humans. Journal of dental research, 80(2), 443-448.https://doi.org/10.1177\%2F00220345010800020801

Lavigne, G., Manzini, C., \& Huynh, N. T. (2011). Sleep bruxism In: Kryger MH, Roth T, Dement WC, editors. Principles and practice of sleep medicine, $1128-39$.

Lin, H. C., Chiang, L. L., Ong, J. H., Tsai, K. L., Hung, C. H., \& Lin, C. Y. (2020). The effects of threshold inspiratory muscle training in patients with obstructive sleep apnea: a randomized experimental study. Sleep and Breathing, 24(1), 201-209. https://doi.org/10.1007/s11325-019-01862-y

Lobbezoo, F., Ahlberg, J., Raphael, K. G., Wetselaar, P., Glaros, A. G., Kato, T., \& Manfredini, D. (2018). International consensus on the assessment of bruxism: Report of a work in progress. Journal of oral rehabilitation, 45(11), 837-844.https://doi.org/10.1111/joor.12663

Mayer, P., Heinzer, R., \& Lavigne, G. (2016). Sleep bruxism in respiratory medicine practice. Chest, 149(1), 262-271. https://doi.org/10.1378/chest.15-0822 Ohayon, M. M., Li, K. K., \& Guilleminault, C. (2001). Risk factors for sleep bruxism in the general population. Chest, 119(1), 53-61. https://doi.org/10.1378/chest.119.1.53 
Research, Society and Development, v. 10, n. 9, e53010918567, 2021

(CC BY 4.0) | ISSN 2525-3409 | DOI: http://dx.doi.org/10.33448/rsd-v10i9.18567

Okeson, J. P., Phillips, B. A., Berry, D. T., Cook, Y. R., \& Cabelka, J. F. (1991). Nocturnal bruxing events in subjects with sleep-disordered breathing and control subjects. Journal of Craniomandibular Disorders, 5(4).

Olsen, S., Smith, S., \& Oei, T. P. (2008). Adherence to continuous positive airway pressure therapy in obstructive sleep apnoea sufferers: a theoretical approach to treatment adherence and intervention. Clinical psychology review, 28(8), 1355-1371. https://doi.org/10.1016/j.cpr.2008.07.004

Remmers, J. E., DeGroot, W. J., Sauerland, E. K., \& Anch, A. M. (1978). Pathogenesis of upper airway occlusion during sleep. Journal of Applied Physiology, 44(6), 931-938. https://doi.org/10.1152/jappl.1978.44.6.931

Saito, M., Yamaguchi, T., Mikami, S., Watanabe, K., Gotouda, A., Okada, K., \& Lavigne, G. (2016). Weak association between sleep bruxism and obstructive sleep apnea. A sleep laboratory study. Sleep and Breathing, 20(2), 703-709.http://doi.org/10.1007/s11325-015-1284-x

Silva, E. (2011). Análise eletromiográfica dos músculos respiratórios em indivíduos saudáveis submetidos a diferentes cargas de treinamento muscular inspiratório (Electromyographic analysis of respiratory muscles in healthy individuals submitted to different loads of inspiratory muscle training). São José dos Campos.

Sjöholm, T. T., Lowe, A. A., Miyamoto, K., Fleetham, J. A., \& Ryan, C. F. (2000). Sleep bruxism in patients with sleep-disordered breathing. Archives of oral biology, 45(10), 889-896. https://doi.org/10.1016/S0003-9969(00)00044-3

Souza, A. K. F., de Andrade, A. D., de Medeiros, A. I. C., de Aguiar, M. I. R., de Souza Rocha, T. D., Pedrosa, R. P., \& de Lima, A. M. J. (2018). Effectiveness of inspiratory muscle training on sleep and functional capacity to exercise in obstructive sleep apnea: a randomized controlled trial. Sleep and Breathing, 22(3), 631-639. https://doi.org/10.1007/s11325-017-1591-5

Strollo Jr, P. J., Soose, R. J., Maurer, J. T., De Vries, N., Cornelius, J., Froymovich, O., \& Strohl, K. P. (2014). Upper-airway stimulation for obstructive sleep apnea. New England Journal of Medicine, 370(2), 139-149. https://www.nejm.org/doi/full/10.1056/NEJMoa1308659

Sullivan, C., Berthon-Jones, M., Issa, F., \& Eves, L. (1981). Reversal of obstructive sleep apnoea by continuous positive airway pressure applied through the nares. The Lancet, 317(8225), 862-865.https://doi.org/10.1016/S0140-6736(81)92140-1

Van de Heyning, P. H., Badr, M. S., Baskin, J. Z., Cramer Bornemann, M. A., De Backer, W. A., Dotan, Y., \& Woodson, B. T. (2012). Implanted upper airway stimulation device for obstructive sleep apnea. The Laryngoscope, 122(7), 1626-1633. https://doi.org/10.1002/lary.23301

Vranish, J. R., \& Bailey, E. F. (2016). Inspiratory muscle training improves sleep and mitigates cardiovascular dysfunction in obstructive sleep apnea. Sleep, 39(6), 1179-1185. https://doi.org/10.5665/sleep.5826

Weaver, T. E., \& Grunstein, R. R. (2008). Adherence to continuous positive airway pressure therapy: the challenge to effective treatment. Proceedings of the American Thoracic Society, 5(2), 173-178. 